\title{
Asbestos Tissue Burden Study on Human Malignant Mesothelioma
}

\author{
Yasunosuke SUZUKI* and Steven R. YUEN
}

\begin{abstract}
Department of Community and Preventive Medicine, Mount Sinai School of Medicine, 1 Gustave L. Levy Place 10029, New York, New York, U.S.A.
\end{abstract}

Received December 15, 2000 and accepted February 13, 2001

\begin{abstract}
Asbestos fibers in the lung and mesothelial tissues (mesotheliomatous tissue and hyaline plaque) taken from 151 human malignant mesothelioma cases were identified and characterized by high resolution analytical electron microscopy. Asbestos fibers were present in almost all of the lung tissue as well as in the mesothelial tissue. The most common asbestos types seen in the lung were an admixture of chrysotile with amphiboles followed by amphiboles alone and chrysotile alone. The majority of asbestos types seen in the mesothelial tissues were chrysotile alone, followed by chrysotile plus amphibole and amphibole alone. A disproportion of asbestos types between the lung and mesothelial tissues was frequently observed. The most common pattern of the disproportion was chrysotile plus amphibole(s) in the lung and chrysotile only in the mesothelial tissues, followed by amphibole(s) in the lung and chrysotile only in the mesothelial tissues. Such a disproportion was considered to have been caused by chrysotile fiber's strong capacity to translocate from the lung to mesothelial tissues. The number of asbestos fibers in the lung was $456.4 \times 10^{6}$ fibers/dry gram in maximum, $0.08 \times 10^{6}$ fibers/dry gram in minimum and $105 \times 10^{6}$ fibers/dry gram on average; in the mesothelial tissues it was $240.0 \times 10^{6}$ fibers/dry gram in maximum, $0.03 \times 10^{6}$ fibers/dry gram in minimum and $49.84 \times 10^{6}$ fibers/dry gram on average. These numbers were greater than those seen in the general population. The majority of asbestos fibers detected in the lung and mesothelial tissues were shorter than $5 \mu \mathrm{m}$ in length. Asbestos fibers fit to Stanton's hypothetical dimensions ( $\geq 8.0 \mu \mathrm{m}$ in length and $\leq 0.25 \mu \mathrm{m}$ in diameter) were only $4.0 \%$, since the majority of these fibers were shorter $(<8 \mu \mathrm{m})$ and thinner $(<0.25 \mu \mathrm{m})$ fibers. We concluded that such short, thin asbestos fibers should not be excluded from those contributing to the induction of human malignant mesothelioma. The present study supports that chrysotile asbestos can induce human malignant mesothelioma, since, in some of the mesothelioma cases, asbestos fibers detected in both the lung and mesothelial tissues, or lung tissue alone or mesothelial tissues alone were exclusively chrysotile fibers.
\end{abstract}

Key words: Mesothelioma, Type and Dimensions of Asbestos Fibers, Chrysotile, Translocation

\section{Introduction}

It is well known that human malignant mesothelioma is caused almost exclusively by exposure to asbestos. It is also known that inhaled asbestos fibers are durable in the lung and persist in the lung and that a part of the fibers are transformed into asbestos bodies after hemosiderin deposits

*To whom correspondence should be addressed. on the surface of the fibers ${ }^{1)}$. Interestingly, however, some of intrapulmonary asbestos fibers, particularly chrysotile fibers are cleared from the lung ${ }^{2}$. It is also known that asbestos fibers are capable of translocating from the lung into other tissues including lymph nodes and mesothelial tissue $^{3-7)}$. There were reports that asbestos bodies were found in various organs other than the lung, supporting that asbestos fibers were disseminated from the lung to other organs ${ }^{8,9)}$.

Asbestos fibers in human tissues can be identified and 
characterized by a high resolution analytical electron microscope, even if they are short and thin in dimension ( $\geq 0.1 \mu \mathrm{m}$ in length and $\geq 0.03 \mu \mathrm{m}$ in width).

Up to the present, to clarify asbestos fibers associated with the induction of human malignant mesothelioma, researchers have been focusing almost exclusively on asbestos fibers in the lung tissue taken from mesothelioma patients ${ }^{10-14)}$.

We have questioned the adequacy of such an approach since; a) the primary site of malignant mesothelioma is not the lung but the mesothelial tissue (pleural or peritoneal). Accordingly, asbestos fibers translocated into the mesothelial tissue should be considered as a more important contributory factor for the induction of malignant mesothelioma, and $b$ ) there is evidence that type and number of asbestos fibers are frequently different between the lung and the mesothelial tissue in mesothelioma cases $^{3-6)}$. Therefore, it may not be logical to say that intrapulmonary asbestos fibers can be blindly used as a definite marker for the induction of the tumor.

It has been emphasized from animal studies that long (greater than $8 \mu \mathrm{m}$ in length) and thin (less than $0.25 \mu \mathrm{m}$ in width) mineral fibers were strongly carcinogenic for the induction of pleural mesothelioma in rats. (Stanton's hypothesis) ${ }^{15}$. His hypothetical dimensions have been directly applied to the counting of the asbestos fibers in human case. The current Occupational and Health Administration (OSHA) method by light microscopy counts asbestos fibers that are longer than $5 \mu \mathrm{m}$ in length with on aspect ratio of larger than 3 to 1 , assuming that all fibers shorter than $5 \mu \mathrm{m}$ are not carcinogenic. Further, even on the electron microscopic level, using the same assumption, some investigators have neglected to count short asbestos fibers $(\leq 5 \mu \mathrm{m})$ in their tissue burden studies ${ }^{12,15-19)}$. However, our previous studies revealed that the majority of asbestos fibers in human lung and mesothelial tissues taken from mesothelioma patients did not fit Stanton's hypothetical dimensions; less than $2 \%$ of chrysotile fibers and less than $10 \%$ of amosite fibers in these tissues fit with Stanton's criteria. Short, thin asbestos fibers were the majority among asbestos fibers detected in these tissues ${ }^{5,6}$. It was strongly suggested that short, thin asbestos fibers are contributive to the induction of malignant mesothelioma and that they should not be categorically excluded from carcinogenic fibers ${ }^{5,6}$.

Asbestos tissue burden study is an effective approach to clarify whether chrysotile fibers are capable of inducing human malignant mesothelioma. If the asbestos type seen in the lung and mesothelial tissues of mesothelioma cases is solely chrysotile, such mesothelioma cases can be considered to have been caused by chrysotile exposure.
Indeed, such cases have been reported elsewhere ${ }^{6,20)}$. To obtain clear answers to the above problems and to identify type, number and dimensions of asbestos fibers contributing to the induction of human malignant mesothelioma, we have done asbestos fiber analyses on the lung and mesothelial tissues (mesotheliomatous tissue in the primary site or pleural hyaline plaque), which were taken from 151 cases of human malignant mesothelioma.

\section{Materials and Methods}

A total of 151 malignant mesothelioma cases of which diagnostic certainty was confirmed as definite or probable by the author were used as materials. The diagnostic certainty was decided by a systematic analysis consisting of gross appearances, histology, histochemistry, immunocytochemistry and electron microscopy (in some cases only). Occupational history of these mesothelioma patients, who were living in the United States, were diverse and included insulation workers, pipe fitters, electricians, shipyard workers, U.S. Navy servicemen, sheet metal workers, power plant workers, boiler men, brake lining mechanics, a fire fighter, a housewife, etc. Asbestos fibers in both the lung and mesothelial tissues (primary mesotheliomatous tissue, or fibrotic serosa including pleural hyaline plaque, or both) were investigated in 64 of the 151 cases. In 43 of the 151 cases, the fibers were exclusively investigated in the lung. In the rest 44 cases, the fibers were also exclusively investigated in mesothelial tissue.

The mesotheliomatous tissue was selected from the primary serosal (pleural or peritoneal) tumor where the tumor was intimately associated with fibrosis and or hyaline plaque. To prepare electron microscopic specimens, either a digestion technique of the bulk tissues using bleach or $\mathrm{KOH}$ solution, or a low temperature ashing technique of $25 \mu \mathrm{m}$ thick section, or both were used. Details of these techniques have been reported elsewhere ${ }^{5,6,20-22)}$.

A high resolution analytical electron microscope was used for the identification and characterization of asbestos fibers in these tissues; ultrastructure, energy dispersive $\mathrm{X}$ ray spectrometry and selected area electron diffraction (in a limited numbers of these cases) were utilized for these purposes. Asbestos fibers measured and those with an aspect ratio of 3:1 and greater were counted in this study, even if they were shorter than $1 \mu \mathrm{m}$ in length.

\section{Observations}

A. In 64 of the 151 cases, asbestos fiber analysis was performed in both the lung and mesothelial tissues, using 
digested bulk samples, ashed sections or both. Results were as follows.

1. Types of asbestos fibers detected in the lung were quite often different from those seen in the mesothelial tissue. The combination of asbestos type between the lung and mesothelial tissues was as follows:

1) Chrysotile plus amphibole(s) in the lung, and chrysotile alone in the mesothelial tissues. $18 / 64$ cases; $28.1 \%$.

2) Chrysotile in the lung, and chrysotile in the mesothelial tissues. $15 / 64 ; 23.3 \%$.

3) Amphibole(s) in the lung, and chrysotile in the mesothelial tissues 13/64; $20.3 \%$.

4) Chrysotile plus amphibole(s) in the lung, and chrysotile plus amphibole(s) in the mesothelial tissues. 8/64; $12.5 \%$.

5) Amphibole(s) in the lung, and chrysotile plus amphibole(s) in the mesothelial tissues. 4/64; 6.3\%.

6) No asbestos fibers in the lung, and chrysotile in the mesothelial tissues. 2/64:3.1\%.

7) Chrysotile in the lung, and chysotile plus amphibole(s) in the mesothelial tissues: $2 / 64 ; 3.1 \%$.

8) Amphibole in the lung, and no asbestos fibers in the mesothelial tissues. $1 / 64 ; 1.6 \%$.

9) Amphibole in the lung, and amphibole in the mesothelial tissues. $1 / 64 ; 1.6 \%$.

In summary, a disproportion of type of asbestos fibers between the two tissues was quite common; it was seen in 40 of the 64 cases $(62.5 \%)$.

2. Asbestos types identified in the lung were chrysotile $(43 / 64 ; 67.2 \%)$, followed by amosite $(43 / 64 ; 67.2 . \%)$, tremolite $(13 / 64 ; 20.3 \%)$, anthophyllite $(11 / 64 ; 17.2 \%)$ and crocidolite $(10 / 64 ; 15.6 \%)$.

3. Chrysotile was the most common asbestos type detected in the mesothelial tissues. It was present in 62 of the 64 cases (96.9\%); chrysotile was exclusively detected in 48 of the 62 cases $(77.4 \%)$.

4. When chrysotile was almost exclusively seen in the lung, asbestos type detected in the mesothelial tissues was also exclusively chrysotile (15/17 cases; $88.2 \%)$.

5. When amphibole(s) was exclusively observed in the lung, asbestos type seen in the mesothelial tissues rarely contained amphibole(s) (1/19 cases; 5.3\%). Other asbestos type(s) seen in the mesothelial tissues were chrysotile alone $(13 / 19 ; 68.4 \%)$, chrysotile plus amphibole(s) $(4 / 19 ; 21.0 \%)$ and no asbestos fibers $(1 / 19 ; 5.3 \%)$.

B. In 43 of the 151 cases, asbestos tissue burden study was carried out in the lung tissue only using digested bulk samples, or ashed tissue sections or both.
Results were as follows:

1. Asbestos types detected in the lung of these 43 cases varied. They were amphibole(s) alone $(18 / 43 ; 41.9 \%)$, followed by chrysotile plus amphibole(s) $(15 / 43 ; 34.9 \%)$ and chrysotile only $(10 / 43 ; 23.3 \%)$.

2. Subtype of amphiboles seen in the lung of 33 of the 43 cases was amosite alone $(17 / 33 ; 51.5 \%)$, followed by amosite plus tremolite $(5 / 33 ; 15.2 \%)$, crocidolite alone $(4 / 33 ; 12.1 \%)$, tremolite alone $(2 / 33 ; 6.1 \%)$, amosite plus crocidolite $(2 / 33 ; 6.1 \%)$, amosite plus crocidolite plus anthophyllite $(2 / 33 ; 6.1 \%)$ and amosite plus anthophyllite $(1 / 33 ; 3.0 \%)$.

C. In 44 of the 151 cases, asbestos tissue burden study was done in the mesothelial tissues only, using digested bulk samples, ashed sections or both. Again, chrysotile fibers were the major asbestos type detected in the mesothelial tissues. Asbestos types seen in the mesothelial tissues were chrysotile alone $(30 / 44 ; 68.2 \%)$, followed by chrysotile with amphibole $(7 / 44 ; 15.9 \%$ [4 with tremolite, 2 with amosite and 1 with anthophyllite]), no asbestos fibers detected (6/ $44 ; 13.6 \%)$ and amosite alone $(1 / 44 ; 2.3 \%)$.

Findings obtained from A, B and C are summarized as follows.

1. Asbestos fibers were present in almost all of the lung tissue $(105 / 107 ; 98.1 \%)$ as well as in the mesothelial tissues $(101 / 108$; 93.5\%).

2. A disproportion of types of asbestos fibers between the lung and the mesothelial tissues was common; it was seen in 41 of the 64 cases (64\%).

3. The most common asbestos types seen in the lung were an admixture of chrysotile with amphiboles (41/105; $39.1 \%$ ) followed by amphiboles alone $(37 / 105 ; 35.2 \%)$ and chrysotile alone $(27 / 105 ; 25.7 \%)$.

4. In the mesothelial tissues, the majority of asbestos type seen was chrysotile $(78 / 101 ; 77.2 \%)$, followed by chrysotile plus amphibole $(21 / 101 ; 20.8 \%)$ and amphibole alone $(2 / 101 ; 2.0 \%)$.

The type of asbestos fibers in the lung and mesothelial tissues among the 151 mesothelioma cases is shown in Table 1.

D. Quantitative analysis of asbestos fibers in the tissues (number of the fibers/dry gram) was done in both digested lung and digested mesothelial tissues taken from 21 mesothelioma cases (Table 2) and from the digested lung taken from additional 23 mesothelioma cases (Table 3). The 21 cases were a part of the 64 cases in $\mathrm{A}$, and the 23 cases were a part of the 43 cases in $\mathrm{B}$. 
Table 1. The type of asbestos fibers in the lung and mesothelial tissues among 151 malignant mesothelioma cases.

A. 64 of 151 cases (asbestos tissue burden study was performed in both the lung and mesothelial tissues).

\begin{tabular}{ccc}
\hline Lung tissue & Mesothelial tissue & No. of Cases \\
\hline C + A & C & 18 \\
C & C & 15 \\
A & C & 13 \\
C + A & C + A & 8 \\
A & C + A & 4 \\
- & C & 2 \\
C & C + A & 2 \\
A & - & 1 \\
A & A & 1 \\
\hline
\end{tabular}

B. 43 of 151 cases (asbestos tissue burden study was performed in the lung tissues alone).

\begin{tabular}{cc}
\hline Lung tissue & No. of Cases \\
\hline A & 18 \\
C + A & 15 \\
C & 10 \\
- & 0 \\
\hline Total & 43 \\
\hline
\end{tabular}

C. 44 of 151 cases (asbestos tissue burden study was performed in the mesothelial tissues alone).

\begin{tabular}{cc}
\hline Mesothelial tissue & No. of Cases \\
\hline C & 30 \\
C + A & 7 \\
- & 6 \\
A & 1 \\
\hline Total & 44 \\
\hline
\end{tabular}

C: Chrysotile, A: Amphibole(s), C + A: Chrysotile and Amphibole(s), - : Not detected.

1. Table 2 (lung and mesothelial tissues; 21 mesothelioma cases). Total number of asbestos fibers detected in the lung tissue was $456.4 \times 10^{6}$ fibers/dry gram in maximum, $0.08 \times 10^{6}$ fibers/dry gram in minimum, and $105 \times 10^{6}$ fibers/dry gram on average. In the mesothelial tissues, the number of the fibers was $240.0 \times 10^{6}$ fibers/dry gram in maximum, $0.03 \times 10^{6}$ fibers/dry gram in minimum, and $49.8 \times 10^{6}$ fibers/dry gram on average.

2. Table 3 (lung tissue only; 23 additional mesothelioma cases). Total number of asbestos fibers detected in the lung was $260 \times 10^{6}$ fibers/dry gram in maximum, 0.08 $\times 10^{6}$ fibers/dry gram in minimum, and $24.2 \times 10^{6}$ fibers/ dry gram on average.

3. Our unpublished data on the number of asbestos fibers in the lung obtained from the general population (18 cases, New Yorkers) showed that $4.9 \times 10^{6}$ fibers/dry gram in maximum, 0 (or < detection limit) fibers/dry gram in minimum, and $0.44 \times 10^{6}$ fibers/dry gram on average. In the mesothelial tissues taken from the general population ( 7 cases, New Yorkers), the number of asbestos fibers was $2.24 \times 10^{6}$ fibers /dry gram in maximum, 0 (or < detection limit) fibers/dry gram in minimum, and $0.41 \times 10^{6}$ fibers/dry gram on average. The vast majority of these asbestos fibers seen in both the lung and the mesothelial tissue were short, thin chrysotile fibers.

In summary, except for three cases, the number of asbestos fibers in the lung of 44 mesothelioma cases ( 21 from Table 2 group and 23 from Table 3 group) was greater than the average number of asbestos fibers in the lung taken from the general population. The number of asbestos fibers in the mesothelial tissues taken from the 21 mesothelioma cases (Table 2 group) was also greater in the majority (17/21) than the average number of the general population.

E. Dimensions (length and diameter) of a total of 2884 asbestos fibers which were present in the lung and the mesothelial tissues (mesotheliomatous tissue and hyaline plaque) taken from the 21 mesothelioma cases (Table 2 group) were measured.

These 2884 asbestos fibers consisted of 1725 chrysotile fibers (495 in lung, 450 in plaque and 780 in tumor), 1042 amosite fibers (959 in lung, 45 in plaque and 38 in tumor), 78 crocidolite fibers (77 in lung, 0 in plaque and 1 in tumor), 19 tremolite fibers (19 in lung, 0 in plaque and 0 in tumor) and 20 anthophyllite fibers (17 in lung, 1 in plaque and 2 in tumor). Results were summarized in Table 3.

Chrysotile fibers were short in length (G.M.: $0.75 \mu \mathrm{m}$ in lung, $0.61 \mu \mathrm{m}$ in hyaline plaque and $0.65 \mu \mathrm{m}$ in tumor) and thin in diameter (G.M.: $0.040 \mu \mathrm{m}$ in lung, $0.04 \mu \mathrm{m}$ in plaque and $0.04 \mu \mathrm{m}$ in tumor). Amosite fibers were greater in length (G.M.: $3.75 \mu \mathrm{m}$ in lung, $2.20 \mu \mathrm{m}$ in plaque and $3.28 \mu \mathrm{m}$ in tumor) and thicker in diameter (G.M; $0.14 \mu \mathrm{m}$ in lung, 0.13 $\mu \mathrm{m}$ in plaque and $0.16 \mu \mathrm{m}$ in tumor). Although other amphibole fibers, such as crocidolite. tremolite and anthophyllite fibers were much smaller in number, results were as follows. Crocidolite fibers length was $3.71 \mu \mathrm{m}$ (G.M.) in lung, not available in plaque and $3.33 \mu \mathrm{m}$ (G.M.) in tumor, and their diameter was $0.10 \mu \mathrm{m}$ (G.M.) in lung, 
Table 2. The type and number of asbestos fibers in lung parenchyma, pleural plaque and mesotheliomatous tissues among 21 cases of mesothelioma

\begin{tabular}{|c|c|c|c|c|c|c|c|c|c|c|}
\hline \multirow[b]{2}{*}{ Cases No. } & \multirow[b]{2}{*}{ Occupation } & \multirow[b]{2}{*}{ Site } & \multirow[b]{2}{*}{ Disease } & \multicolumn{7}{|c|}{ Abestos fibers (*) } \\
\hline & & & & Chry & Amos & Croc & Anth & $\mathrm{Tr} / \mathrm{Ac}$ & D.L. & Total \# \\
\hline \multirow[t]{2}{*}{1} & Insulation & $\mathrm{L}$ & Pl. Meso & 28.3 & 125 & $<\mathrm{DL}$ & 2.83 & $<\mathrm{DL}$ & 2.83 & 156.1 \\
\hline & Worker & $\mathrm{P}$ & & 12.1 & 1.29 & $<\mathrm{DL}$ & $<\mathrm{DL}$ & $<\mathrm{DL}$ & 0.16 & 13.4 \\
\hline \multirow[t]{3}{*}{2} & Insulation & $\mathrm{L}$ & Pl. Meso & 28.6 & 194 & $<\mathrm{DL}$ & 3 & 3 & 1.5 & 228.6 \\
\hline & Worker & $\mathrm{P}$ & & 39.2 & 0.6 & $<\mathrm{DL}$ & $<\mathrm{DL}$ & $<\mathrm{DL}$ & 0.6 & 39.8 \\
\hline & & $\mathrm{T}$ & & 62.1 & $<\mathrm{DL}$ & $<\mathrm{DL}$ & $<\mathrm{DL}$ & $<\mathrm{DL}$ & 1.27 & 62.1 \\
\hline \multirow[t]{3}{*}{3} & Insulation & $\mathrm{L}$ & Pe. Meso & 24 & 139 & 7.37 & $<\mathrm{DL}$ & 11.4 & 1.26 & 181.8 \\
\hline & Worker & $\mathrm{P}$ & & 36.3 & 6.34 & $<\mathrm{DL}$ & $<\mathrm{DL}$ & $<\mathrm{DL}$ & 0.58 & 92.6 \\
\hline & & $\mathrm{T}$ & & 14.8 & $<\mathrm{DL}$ & $<\mathrm{DL}$ & $<\mathrm{DL}$ & $<\mathrm{DL}$ & 0.76 & 14 \\
\hline \multirow[t]{3}{*}{4} & Insulation & $\mathrm{L}$ & Pe. Meso & 111 & 282 & 25.6 & 4.3 & $<\mathrm{DL}$ & 2.13 & 422.9 \\
\hline & Worker & $\mathrm{P}$ & & 31.8 & 6.81 & $<\mathrm{DL}$ & $<\mathrm{DL}$ & $<\mathrm{DL}$ & 0.76 & 38.6 \\
\hline & & $\mathrm{T}$ & & 16.5 & 0.52 & $<\mathrm{DL}$ & $<\mathrm{DL}$ & $<\mathrm{DL}$ & 0.17 & 17 \\
\hline \multirow[t]{3}{*}{5} & Insulation & $\mathrm{L}$ & Pe. Meso & 25.5 & 120 & $<\mathrm{DL}$ & $<\mathrm{DL}$ & $<\mathrm{DL}$ & 0.77 & 145.5 \\
\hline & Worker & $\mathrm{P}$ & & 29.4 & 1.8 & $<\mathrm{DL}$ & $<\mathrm{DL}$ & $<\mathrm{DL}$ & 0.6 & 31.2 \\
\hline & & $\mathrm{T}$ & & 12.6 & 1.76 & $<\mathrm{DL}$ & $<\mathrm{DL}$ & $<\mathrm{DL}$ & 0.44 & 14.4 \\
\hline \multirow[t]{3}{*}{6} & Insulation & $\mathrm{L}$ & Pe. Meso & 91.9 & 213 & 86.4 & $<\mathrm{DL}$ & 3.68 & 1.84 & 395 \\
\hline & Worker & $\mathrm{T}$ & & 50.1 & 1.79 & $<\mathrm{DL}$ & $<\mathrm{DL}$ & $<\mathrm{DL}$ & 0.6 & 51.9 \\
\hline & & $\mathrm{T}$ & & 43.7 & $<\mathrm{DL}$ & $<\mathrm{DL}$ & $<\mathrm{DL}$ & $<\mathrm{DL}$ & 0.48 & 43.7 \\
\hline \multirow[t]{2}{*}{7} & Insulation & $\mathrm{L}$ & Pe. Meso & 18.8 & 415 & 11.3 & $<\mathrm{DL}$ & 11.3 & 3.75 & 456.4 \\
\hline & Worker & $\mathrm{T}$ & & 90 & 14 & $<\mathrm{DL}$ & $<\mathrm{DL}$ & $<\mathrm{DL}$ & 1.42 & 104 \\
\hline \multirow[t]{2}{*}{8} & Insulation & $\mathrm{L}$ & Pe. Meso & 1.5 & 7.1 & $<\mathrm{DL}$ & $<\mathrm{DL}$ & $<\mathrm{DL}$ & 0.29 & 8.5 \\
\hline & Worker & $\mathrm{T} / \mathrm{P}$ & & 17 & $<\mathrm{DL}$ & $<\mathrm{DL}$ & $<\mathrm{DL}$ & $<\mathrm{DL}$ & 0.26 & 17 \\
\hline \multirow[t]{2}{*}{9} & Engineer & $\mathrm{L}$ & Pl. Meso & $<\mathrm{DL}$ & 2.5 & 0.53 & $<\mathrm{DL}$ & $<\mathrm{DL}$ & 0.18 & 30 \\
\hline & & $\mathrm{T}$ & & 22.5 & $<\mathrm{DL}$ & 0.22 & 0.22 & $<\mathrm{DL}$ & 0.22 & 22.94 \\
\hline \multirow[t]{2}{*}{10} & Aircraft & $\mathrm{L}$ & Pl. Meso & 61 & $<\mathrm{DL}$ & $<\mathrm{DL}$ & $<\mathrm{DL}$ & 0.7 & 0.35 & 61.7 \\
\hline & Inspector & $\mathrm{T}$ & & 120 & $<\mathrm{DL}$ & $<\mathrm{DL}$ & $<\mathrm{DL}$ & $<\mathrm{DL}$ & 0.35 & 120 \\
\hline \multirow[t]{2}{*}{11} & Power & $\mathrm{L}$ & Pl. Meso & $<\mathrm{DL}$ & 47 & $<\mathrm{DL}$ & $<\mathrm{DL}$ & $<\mathrm{DL}$ & 2.9 & 41 \\
\hline & Plant & $\mathrm{T}$ & & 240 & $<\mathrm{DL}$ & $<\mathrm{DL}$ & $<\mathrm{DL}$ & $<\mathrm{DL}$ & 2.9 & 240 \\
\hline \multirow[t]{2}{*}{12} & Shipyard \& & $\mathrm{L}$ & Pl. Meso & $<\mathrm{DL}$ & 2.6 & $<\mathrm{DL}$ & $<\mathrm{DL}$ & $<\mathrm{DL}$ & 0.22 & 2.6 \\
\hline & powerhouse & $\mathrm{T}$ & & 51.3 & $<\mathrm{DL}$ & $<\mathrm{DL}$ & $<\mathrm{DL}$ & $<\mathrm{DL}$ & 0.27 & 51.3 \\
\hline \multirow[t]{2}{*}{13} & Powerhouse & $\mathrm{L}$ & Pl. Meso & $<\mathrm{DL}$ & 1.3 & $<\mathrm{DL}$ & 0.15 & 0.15 & 0.15 & 1.6 \\
\hline & & $\mathrm{T}$ & & 2.6 & 0.3 & $<\mathrm{DL}$ & $<\mathrm{DL}$ & $<\mathrm{DL}$ & 0.15 & 2.9 \\
\hline \multirow[t]{2}{*}{14} & Welder & $\mathrm{L}$ & Pl. Meso & 0.62 & $<\mathrm{DL}$ & $<\mathrm{DL}$ & 0.26 & $<\mathrm{DL}$ & 0.26 & 0.88 \\
\hline & & $\mathrm{T}$ & & 0.7 & 0.4 & $<\mathrm{DL}$ & 0.3 & $<\mathrm{DL}$ & 0.09 & 1.4 \\
\hline 15 & US Navy & $\mathrm{L}$ & Pl. Meso & 27 & $<\mathrm{DL}$ & $<\mathrm{DL}$ & $<\mathrm{DL}$ & $<\mathrm{DL}$ & 4.4 & 27 \\
\hline & & $\mathrm{T}$ & & 22 & $<\mathrm{DL}$ & $<\mathrm{DL}$ & $<\mathrm{DL}$ & $<\mathrm{DL}$ & 0.88 & 22 \\
\hline 16 & Electrician & $\mathrm{L}$ & Pl. Meso & $<\mathrm{DL}$ & 19.2 & 2.9 & $<\mathrm{DL}$ & $<\mathrm{DL}$ & 1.45 & 22.1 \\
\hline & & $\mathrm{T} / \mathrm{P}$ & & 228.2 & 1.8 & $<\mathrm{DL}$ & $<\mathrm{DL}$ & $<\mathrm{DL}$ & 2.9 & 230 \\
\hline 17 & Firefighter & $\mathrm{L}$ & Pl. Meso & 32.5 & 1.4 & $<\mathrm{DL}$ & $<\mathrm{DL}$ & $<\mathrm{DL}$ & 1.77 & 33.9 \\
\hline & & $\mathrm{T} / \mathrm{P}$ & & 16.6 & $<\mathrm{DL}$ & $<\mathrm{DL}$ & $<\mathrm{DL}$ & $<\mathrm{DL}$ & 0.22 & 16.6 \\
\hline 18 & US Navy & $\mathrm{L}$ & Pl. Meso & $<\mathrm{DL}$ & 0.08 & $<\mathrm{DL}$ & $<\mathrm{DL}$ & $<\mathrm{DL}$ & 0.02 & 0.08 \\
\hline & and railroa & $\mathrm{T}$ & & 0.06 & $<\mathrm{DL}$ & $<\mathrm{DL}$ & $<\mathrm{DL}$ & $<\mathrm{DL}$ & 0.03 & 0.6 \\
\hline 19 & US Navy & $\mathrm{L}$ & Pl. Meso & $<\mathrm{DL}$ & 0.52 & $<\mathrm{DL}$ & $<\mathrm{DL}$ & $<\mathrm{DL}$ & 0.03 & 0.52 \\
\hline & & $\mathrm{T}$ & & 2.6 & $<\mathrm{DL}$ & $<\mathrm{DL}$ & $<\mathrm{DL}$ & $<\mathrm{DL}$ & 0.11 & 2.6 \\
\hline 20 & Sheetmetal & $\mathrm{L}$ & Pl. Meso & 0.49 & $<\mathrm{DL}$ & $<\mathrm{DL}$ & 0.04 & $<\mathrm{DL}$ & 0.04 & 0.52 \\
\hline & & $\mathrm{T}$ & & 0.19 & $<\mathrm{DL}$ & $<\mathrm{DL}$ & 0.04 & $<\mathrm{DL}$ & 0.04 & 0.23 \\
\hline 21 & Roofer & $\mathrm{L}$ & Pl. Meso & 1.5 & 0.03 & $<\mathrm{DL}$ & $<\mathrm{DL}$ & $<\mathrm{DL}$ & 0.03 & 1.53 \\
\hline & & $\mathrm{T}$ & & 0.3 & $<\mathrm{DL}$ & $<\mathrm{DL}$ & $<\mathrm{DL}$ & $<\mathrm{DL}$ & 0.03 & 0.03 \\
\hline
\end{tabular}

$\left.{ }^{*}\right): \times 10^{6}$ gram (dry tissue), L: Lung, P: Plaque, T: Tumor, T/P: Tumor/Plaque, D.L.: Detection Limit, <DL: under detection limit (no detection). Chry: chrysotile, Amos: amosite, Croc: crocidolite, Anth: anthophyllite, Tr/Ac: tremolite/actinolite, $\mathrm{Pl}$ : pleura, $\mathrm{Pe:}$ peritoneum, Meso: mesothelioma. 
Table 3. The type and number of asbestos fibers in lung parenchyma in 23 additional cases of mesothelioma

\begin{tabular}{|c|c|c|c|c|c|c|c|c|c|}
\hline \multirow[b]{2}{*}{ Cases No. } & \multirow[b]{2}{*}{ Occupation } & \multirow[b]{2}{*}{ Site } & \multicolumn{7}{|c|}{ Abestos fibers $(*)$} \\
\hline & & & Chry & Amos & Croc & Anth & $\operatorname{Tr} / \mathrm{Ac}$ & D.L. & Total \# \\
\hline \multirow[t]{2}{*}{1} & Electrician & $\mathrm{L}(\mathrm{L})$ & 0.04 & 0.08 & 0.02 & 0.02 & $<\mathrm{DL}$ & $0.02 \times 10^{6}$ & $0.16 \times 10^{6}$ \\
\hline & & $\mathrm{L}(\mathrm{R})$ & 12.1 & 1.29 & $<\mathrm{DL}$ & $<\mathrm{DL}$ & $<\mathrm{DL}$ & $0.03 \times 10^{6}$ & $0.26 \times 10^{6}$ \\
\hline 2 & U.S. Navy & $\mathrm{L}$ & $<\mathrm{DL}$ & 3.3 & $<\mathrm{DL}$ & $<\mathrm{DL}$ & $<\mathrm{DL}$ & $0.17 \times 10^{6}$ & $3.3 \times 10^{6}$ \\
\hline 3 & Insulation worker & $\mathrm{L}$ & $<\mathrm{DL}$ & 0.6 & $<\mathrm{DL}$ & $<\mathrm{DL}$ & 0.9 & $0.26 \times 10^{6}$ & $1.5 \times 10^{6}$ \\
\hline \multirow[t]{2}{*}{4} & Family contact & L-1 & $<\mathrm{DL}$ & 0.11 & $<\mathrm{DL}$ & 0.11 & 0.33 & $0.17 \times 10^{6}$ & $0.56 \times 10^{6}$ \\
\hline & & L-2 & $<\mathrm{DL}$ & $<\mathrm{DL}$ & $<\mathrm{DL}$ & 0.31 & 0.31 & $0.29 \times 10^{6}$ & $0.6 \times 10^{6}$ \\
\hline 5 & Jet plane mechanic & $\mathrm{L}$ & 260 & $<\mathrm{DL}$ & $<\mathrm{DL}$ & $<\mathrm{DL}$ & $<\mathrm{DL}$ & $0.22 \times 10^{6}$ & $260 \times 10^{6}$ \\
\hline 6 & Mechanic & $\mathrm{L}$ & 76 & 0.98 & $<\mathrm{DL}$ & 0.16 & $<\mathrm{DL}$ & $0.12 \times 10^{6}$ & $77.1 \times 10^{6}$ \\
\hline 7 & Construction worker & $\mathrm{L}$ & $<\mathrm{DL}$ & 9.9 & $<\mathrm{DL}$ & $<\mathrm{DL}$ & $<\mathrm{DL}$ & $0.13 \times 10^{6}$ & $9.9 \times 10^{6}$ \\
\hline 8 & U.S. Navy & $\mathrm{L}$ & $<\mathrm{DL}$ & 2.78 & $<\mathrm{DL}$ & 0.22 & $<\mathrm{DL}$ & $0.11 \times 10^{6}$ & $3.0 \times 10^{6}$ \\
\hline 9 & Insulation worker & $\mathrm{L}$ & $<\mathrm{DL}$ & 7.06 & $<\mathrm{DL}$ & $<\mathrm{DL}$ & $<\mathrm{DL}$ & $0.11 \times 10^{6}$ & $7.0 \times 10^{6}$ \\
\hline 10 & Insulation worker & $\mathrm{L}$ & $<\mathrm{DL}$ & 26 & $<\mathrm{DL}$ & $<\mathrm{DL}$ & $<\mathrm{DL}$ & $0.22 \times 10^{6}$ & $26.0 \times 10^{6}$ \\
\hline 11 & Construction worker & $\mathrm{L}$ & 36 & 7.5 & $<\mathrm{DL}$ & $<\mathrm{DL}$ & $=\mathrm{DL}$ & $0.75 \times 10^{6}$ & $43.0 \times 10^{6}$ \\
\hline 12 & Electrician & $\mathrm{L}$ & 1.5 & 1 & 0.5 & $<\mathrm{DL}$ & $<\mathrm{DL}$ & $0.25 \times 10^{6}$ & $3.0 \times 10^{6}$ \\
\hline 13 & Pipe fitter & $\mathrm{L}$ & 1.26 & 0.63 & 2.8 & 0.63 & $<\mathrm{DL}$ & $0.33 \times 10^{6}$ & $5.32 \times 10^{6}$ \\
\hline 14 & U.S. Navy & $\mathrm{L}$ & 16 & $<\mathrm{DL}$ & 0.22 & $<\mathrm{DL}$ & $<\mathrm{DL}$ & $0.22 \times 10^{6}$ & $16.2 \times 10^{6}$ \\
\hline 15 & Insulation worker & $\mathrm{L}$ & 88 & $<\mathrm{DL}$ & $<\mathrm{DL}$ & $<\mathrm{DL}$ & $<\mathrm{DL}$ & $0.44 \times 10^{6}$ & $88.0 \times 10^{6}$ \\
\hline 16 & U.S. Navy & $\mathrm{L}$ & $<\mathrm{DL}$ & 1.64 & 0.12 & 0.5 & $<\mathrm{DL}$ & $0.12 \times 10^{6}$ & $2.26 \times 10^{6}$ \\
\hline 17 & Shipyard & $\mathrm{L}$ & 0.66 & 1.32 & $<\mathrm{DL}$ & $<\mathrm{DL}$ & $<\mathrm{DL}$ & $\mathrm{n} / \mathrm{a}$ & $1.96 \times 10^{6}$ \\
\hline 18 & U.S. Navy & $\mathrm{L}$ & 0.94 & 0.38 & $<\mathrm{DL}$ & $<\mathrm{DL}$ & $<\mathrm{DL}$ & $\mathrm{n} / \mathrm{a}$ & $1.32 \times 10^{6}$ \\
\hline 19 & Boiler repairman & $\mathrm{L}$ & $<\mathrm{DL}$ & 0.35 & $<\mathrm{DL}$ & 0.07 & 0.97 & $0.02 \times 10^{6}$ & $0.52 \times 10^{6}$ \\
\hline \multirow[t]{2}{*}{20} & Pipe fitter & $\mathrm{L}(\mathrm{L})$ & 3 & $<\mathrm{DL}$ & $<\mathrm{DL}$ & $<\mathrm{DL}$ & $<\mathrm{DL}$ & $0.05 \times 10^{6}$ & $3.0 \times 10^{6}$ \\
\hline & & $\mathrm{L}(\mathrm{R})$ & 0.03 & $<\mathrm{DL}$ & $<\mathrm{DL}$ & $<\mathrm{DL}$ & $<\mathrm{DL}$ & $0.03 \times 10^{6}$ & $0.03 \times 10^{6}$ \\
\hline 21 & Boiler repairman & $\mathrm{L}$ & 2.9 & $<\mathrm{DL}$ & $<\mathrm{DL}$ & $<\mathrm{DL}$ & 0.07 & $0.04 \times 10^{6}$ & $3.6 \times 10^{6}$ \\
\hline 22 & Shipyard & $\mathrm{L}$ & $<\mathrm{DL}$ & 0.08 & $<\mathrm{DL}$ & $<\mathrm{DL}$ & $<\mathrm{DL}$ & $0.03 \times 10^{6}$ & $0.08 \times 10^{6}$ \\
\hline 23 & Shipyard & $\mathrm{L}$ & $<\mathrm{DL}$ & 0.11 & 0.1 & $<\mathrm{DL}$ & 0.08 & $0.02 \times 10^{6}$ & $3.29 \times 10^{6}$ \\
\hline
\end{tabular}

$(*): \times 10^{6}$ gram (dry tissue), L: Lung, P: Plaque, T: Tumor, T/P: Tumor/Plaque, D.L.: Detection Limit, <DL: under detection limit (no detection). Chry: chrysotile, Amos: amosite, Croc: crocidolite, Anth: anthophyllite, Tr/Ac: tremolite/actinolite, (L): left, (R): right, n/a: not available.

not available in plaque and $0.32 \mu \mathrm{m}$ (G.M.) in tumor. Tremolite fibers length was $2.75 \mu \mathrm{m}$ (G.M.) in lung, and their diameter was $0.19 \mu \mathrm{m}$ (G.M.) in lung; data was not available in both plaque and tumor, since tremolite fibers were not detected in these tissues. Anthophyllite fibers length was $6.93 \mu \mathrm{m}$ (G.M.) in lung, $1.00 \mu \mathrm{m}$ (G.M.) in plaque and $7.98 \mu \mathrm{m}$ (G.M.) in tumor, and their diameter was $0.55 \mu \mathrm{m}$ (G.M.) in lung, $0.03 \mu \mathrm{m}$ (G.M.) in plaque and $0.65 \mu \mathrm{m}$ in tumor.

The above findings for the fiber dimensions are summarized in Table 4.

F. Asbestos fibers greater than $5 \mu \mathrm{m}$ in length were measured in the 2884 fibers. Results were summarized in Table 5A. Only $18.6 \%$ (537/2884) of the fibers were longer than $5 \mu \mathrm{m}$ in length. $81.4 \%$ were shorter than $5 \mu \mathrm{m}$ as shown in Table $5 \mathrm{~A}$.

To identify asbestos fibers which fit Stanton's hypothetical dimensions, ( $\geq 8 \mu \mathrm{m}$ in length and $\leq 0.25 \mu \mathrm{m}$ in diameter), dimensions of the above 2884 asbestos fibers were examined. Table 5B summarizes which of the 2884 asbestos fibers measured fit into Stanton's criteria of $\geq 8 \mu \mathrm{m}$ in length and $\leq 0.25 \mu \mathrm{m}$ in diameter. Of the 2884 fibers, only 116 fibers (4.0\%) fit Stanton's hypothetical dimensions. Results were summarized in Table 5B. Chrysotile fibers (1725 fibers) fit to the dimensions were $0.6 \%$ (3/495) in lung, $1.6 \%$ (7/436) 
Table 4. Dimensions of $\mathbf{2 , 8 8 4}$ asbestos fibers detected in lung and mesothelial tissues. Totals for the 21 cases (from Table 2)

\begin{tabular}{|c|c|c|c|c|c|c|c|c|c|c|}
\hline \multirow{2}{*}{$\begin{array}{l}\text { Case } \\
\text { Tissue }\end{array}$} & \multicolumn{5}{|c|}{ Length } & \multicolumn{5}{|c|}{ Width } \\
\hline & $\mathrm{N}$ & G.M. & G.S.D. & Min. & Max. & $\mathrm{N}$. & G.M. & G.S.D. & Min. & Max. \\
\hline \multicolumn{11}{|l|}{ Amosite } \\
\hline Lung & 959 & 3.75 & 3.02 & 0.20 & 77.4 & 959 & 0.14 & 2.54 & 0.02 & 2.30 \\
\hline Plaque & 45 & 2.20 & 3.61 & 0.15 & 28.0 & 45 & 0.13 & 2.45 & 0.02 & 0.68 \\
\hline Tumor & 38 & 3.28 & 2.81 & 0.40 & 25.0 & 38 & 0.16 & 1.98 & 0.03 & 0.70 \\
\hline \multicolumn{11}{|l|}{ Chrysotile } \\
\hline Lung & 495 & 0.75 & 2.55 & 0.12 & 18.5 & 495 & 0.04 & 1.63 & 0.02 & 3.00 \\
\hline Plaque & 450 & 0.61 & 2.86 & 0.10 & 38.0 & 450 & 0.04 & 1.45 & 0.02 & 0.20 \\
\hline Tumor & 780 & 0.65 & 2.79 & 0.07 & 15.0 & 780 & 0.04 & 1.56 & 0.01 & 0.70 \\
\hline \multicolumn{11}{|l|}{ Crocidolite } \\
\hline Lung & 77 & 3.71 & 2.23 & 0.70 & 36.0 & 77 & 0.10 & 1.65 & 0.04 & 0.60 \\
\hline Plaque & - & - & - & - & - & - & - & - & - & - \\
\hline Tumor & 1 & 3.33 & 1.0 & 3.33 & 3.33 & 1 & 0.32 & 1.0 & 0.32 & 0.32 \\
\hline \multicolumn{11}{|l|}{ Tremolite } \\
\hline Lung & 19 & 2.75 & 2.74 & 0.60 & 26.0 & 19 & 0.19 & 2.65 & 0.05 & 1.80 \\
\hline Plaque & - & - & - & - & - & - & - & - & - & - \\
\hline Tumor & - & - & - & - & - & - & - & - & - & - \\
\hline \multicolumn{11}{|c|}{ Anthophyllite } \\
\hline Lung & 17 & 6.93 & 3.06 & 1.20 & 49.6 & 17 & 0.55 & 2.13 & 0.10 & 1.50 \\
\hline Plaque & 1 & 1.00 & 1.0 & 1.00 & 1.00 & 1 & 0.03 & 1.00 & 0.30 & 0.30 \\
\hline Tumor & 2 & 7.98 & 5.40 & 2.42 & 26.3 & 2 & 0.65 & 1.85 & 0.42 & 1.00 \\
\hline
\end{tabular}

N: number; G.M.: geometric mean; G.S.D.: geometric standard deviation.

Table 5A. Total number of fibers in lung, plaque and mesotheliomatous tissues greater than $5 \mu \mathrm{m}$ in length

\begin{tabular}{lcl}
\hline Amosite & $418 / 1042$ & $(40.1 \%)$ \\
Crocidolite & $28 / 78$ & $(35.9)$ \\
Tremolite & $4 / 19$ & $(21.1 \%)$ \\
Anthophyllite & $9 / 20$ & $(45.0 \%)$ \\
Chrysotile & $78 / 1725$ & $(4.52 \%)$ \\
\hline & $537 / 2884$ & $(18.6 \%)$ \\
\hline
\end{tabular}

Table 5B. Number of fibers found whose Length $>=8 \mu \mathrm{m} \&$ Diameter $<=0.25 \mu \mathrm{m}$ (From Table 2, 21 Mesothelioma cases).

\begin{tabular}{lclclcl}
\hline & \multicolumn{2}{c}{ Lung } & \multicolumn{2}{c}{ Plaque } & \multicolumn{2}{c}{ Tumor } \\
\hline Amosite & $84 / 959$ & $(8.8 \%)$ & $2 / 45$ & $(4.4 \%)$ & $3 / 38$ & $(7.9 \%)$ \\
Crocidolite & $13 / 77$ & $(16.9 \%)$ & $0 / 0$ & $(0.0 \%)$ & $0 / 1$ & $(0.0 \%)$ \\
Tremolite & $0 / 19$ & $(0.0 \%)$ & $0 / 0$ & $(0.0 \%)$ & $0 / 0$ & $(0.0 \%)$ \\
Anthophyllite & $0 / 17$ & $(0.0 \%)$ & $0 / 1$ & $(0.0 \%)$ & $0 / 2$ & $(0.0 \%)$ \\
Chrysotile & $3 / 495$ & $(0.6 \%)$ & $7 / 450$ & $(1.6 \%)$ & $4 / 780$ & $(0.5 \%)$ \\
\hline & $100 / 1567(6.4 \%)$ & $9 / 496$ & $(1.8 \%)$ & $7 / 821$ & $(0.8 \%)$ \\
\hline
\end{tabular}

in plaque and $0.5 \%(4 / 780)$ in tumor. Amosite fibers (1042 fibers) were $8.8 \%$ (84/959) in lung, $4.4 \%$ (2/45) in plaque and $7.9 \%(3 / 38)$ in tumor. Crocidolite fibers (78 fibers) were $16.9 \%$ in the lung $(13 / 77)$ and $0 \%$ in both plaque $(0 / 0)$ and tumor (0/1). Both tremolite (20 fibers) and anthophyllite (29 fibers) were $0 \%$ in these tissues.

It was concluded that asbestos fibers fit to the Stanton's hypothesis were proportionally small in number in all types of asbestos fibers detected in both the lung and the mesothelial tissues.

\section{Comments}

LeBouffant et al. ${ }^{23)}$, discovered a deposition of a large number of short, thin chrysotile fibers in pleural hyaline plaque (fibrotic parietal pleura) taken from asbestos workers under a transmission electron microscope. It was an important finding at that time, since pathologists could not obviously identify coated or uncoated asbestos fibers in the hyaline plaque in routine histopathologic slides under a light microscope, although they knew that this unique pleural 
alteration was intimately related to exposure to asbestos. Sébastien $e t$ al. $^{3)}$, found a disproportion of type and number of asbestos types between the lung and the parietal pleura among 29 asbestos workers and that most of asbestos fibers seen in the parietal pleura were short chrysotile fibers. Dodson et al. ${ }^{4)}$, found asbestos fibers (predominantly chrysotile) in pleural hyaline plaque taken from 8 cases of shipyard workers. Boutin et al. ${ }^{24)}$, also found highly concentrated asbestos fibers in black spots (glomerate lymphatic capillaries stained dark due to anthracotic pigmentation) in the parietal pleura. They said that amphibole outnumbered chrysotile in the black spots.

Our previous studies ${ }^{5,6}$, revealed that the type of asbestos fibers were quite often different between lung and mesothelial tissues in mesothelioma cases and that the major asbestos type seen in the mesothelial tissues were short, thin chrysotile fibers.

Our present study based on larger numbers of tissue samples showed the same trend for the disproportion of asbestos types between the two tissues. We have previously suggested that such a disproportion was caused by the strong ability of chrysotile fibers to translocate from the lung to the pleura and peritoneum ${ }^{5,6}$. The present study also supported such an idea. To clarify asbestos fibers contributing to the induction of malignant mesothelioma, asbestos tissue burden study should be done in both the lung and mesothelial tissues, because the disproportion of type and number of asbestos fibers between the two tissues is not rare. If asbestos tissue burden study is limited to lung tissue, then translocated asbestos fibers from the lung to the mesothelial tissues will be overlooked. In the present study, it was observed that when asbestos fibers detected in the lung were exclusively chrysotile, asbestos type seen in the mesothelial tissues was also exclusively chrysotile ( $15 / 17$ cases; $88.2 \%$ ).

The passage route of the fibers has not been fully understood, although three ways of the passage are considered: 1) a direct migration of the fibers from the lung to the parietal pleura through the pleural cavity, and also to the peritoneum through the lung, pleural cavity and diaphragm; 2) through a lymphatic capillary system; and 3) through a blood capillary system.

The number of asbestos fibers observed per gram in the lung and the mesothelial tissues varied. It was larger than the average number in the general population in $43 / 44$ cases [97.7\%] in the lung and in $17 / 21$ cases [ $81 \%$ ] in the mesothelial tissues. The number of fibers (chrysotile in the vast majority) in mesothelial tissues was larger than that seen in the lung in some cases $(8 / 21 ; 38.1 \%)$. Numerical ratio between chrysotile fibers and amphibole(s) fibers in the mesothelial tissues was examined in 12 of the 21 mesothelial tissues in which both asbestos types were present (Table 2). It was approximately 18.0 (chrysotile): 1 (amphibole[s]) in the mesothelial tissues.

Our present study revealed that the majority of asbestos fibers detected in the lung and mesothelial tissues were shorter than $5 \mu \mathrm{m}$; only $18.6 \%$ (537/2884) of the fibers were longer than $5 \mu \mathrm{m}$ in length. It was also established that asbestos fibers fitting to Stanton's hypothetical dimensions ( $\geq 8 \mu \mathrm{m}$ in length and $\leq 0.25 \mu \mathrm{m}$ in diameter) were only $4 \%$ (116/ 2884) among the fibers detected in these tissues.

From these findings, it is obvious that if we exclusively count asbestos fibers longer than $5 \mu \mathrm{m}$ or if we select only asbestos fibers fitting to Stanton's hypothetical dimensions, a large proportion of asbestos fibers in these tissues will be omitted, since the majority are shorter than $5 \mu \mathrm{m}$ in length, although the diameter of these short fibers does generally fit well to Stanton's width parameters.

It should be taken into account that such short, thin asbestos fibers are carcinogenic, since they are the majority in the lung and the mesothelial tissues taken from mesothelioma cases. It has been generally accepted that like other asbestos types, chrysotile fibers are capable of inducing human malignant mesothelioma ${ }^{25-28}$. This conclusion has been obtained from various sources including molecular biological studies $^{29-33)}$, animal experiments ${ }^{2,15,34-38)}$, epidemiological studies $^{39-44)}$, case reports ${ }^{45-48)}$, and asbestos tissue burden studies ${ }^{6,20)}$.

The present study on asbestos tissue burden further supports the evidence that chrysotile fibers were capable of inducing human malignant mesothelioma, since a) chrysotile was the most common asbestos type seen in the mesothelial tissues which is the original site of the induction of mesothelioma and b) chrysotile was exclusively seen in both the lung and the mesothelial tissues in 15/64 (23.3\%) cases, in the lung tissue alone in 10/43 (23.3\%) and in the mesothelial tissues alone in $30 / 44(68.2 \%)$ cases.

\section{Summary}

To identify and characterize asbestos fibers contributing to the induction of human malignant mesothelioma, asbestos fibers in the lung and mesothelial tissues (mesotheliomatous tissue and hyaline plaque) taken from 151 human malignant mesothelioma cases were investigated by a high resolution analytical electron microscope. Results were as follows:

1) Asbestos fibers were present in almost all of the lung tissue as well as in the mesothelial tissue.

2) The most common asbestos types seen in the lung were 
an admixture of chrysotile with amphiboles (41/105; $39.1 \%)$, followed by amphiboles alone $(37 / 105 ; 35.2 \%)$ and chrysotile alone $(27 / 105 ; 25.7 \%)$. The majority of asbestos types seen in the mesothelial tissues were chrysotile alone ( $78 / 101 ; 77.2 \%)$, followed by chrysotile plus amphibole $(21 / 101 ; 20.8 \%)$ and amphibole alone $(2 / 101 ; 2.0 \%)$.

3) A disproportion of asbestos types between the lung and mesothelial tissues was frequently observed. The most common pattern of the disproportion was chrysotile plus amphibole(s) in the lung and chrysotile only in mesothelial tissues (18/64), followed by amphibole(s) in the lung and chrysotile only in mesothelial tissues $(13 / 64)$. It was considered that such a disproportion was caused by chrysotile fibers' strong capacity to translocate from the lung to the mesothelial tissues.

4) The number of asbestos fibers in both the lung and the mesothelial tissues was various among the mesothelioma cases. In the lung (44 cases), it was 456.4 $\times 10^{6}$ fibers /dry gram in maximum, $0.08 \times 10^{6}$ fibers/ dry gram in minimum and $77.7 \times 10^{6}$ fibers /dry gram on average. In the mesothelial tissue (21 cases), it was $240.0 \times 10^{6}$ fibers/dry gram in maximum, $0.03 \times 10^{6}$ fibers/dry gram in minimum and $49.84 \times 10^{6}$ fibers/ dry gram on average. These numbers were greater than those seen in the general population. Occasionally the number of asbestos fibers in the mesothelial tissues was larger than that of those seen in the lung. The number of chrysotile fibers was 18.1 times greater than that of amphibole fibers in the mesothelial tissues taken from 12 cases in which both asbestos types were detected.

5) The majority $(81.4 \% ; 2347 / 2884)$ of asbestos fibers detected in the lung and mesothelial tissues were shorter than $5 \mu \mathrm{m}$ in length. Asbestos fibers fit to Stanton's hypothetical dimensions ( $\geq 8.0 \mu \mathrm{m}$ in length and $\leq 0.25$ $\mu \mathrm{m}$ in diameter) were only $4.0 \%$ (116/2884), since the majority of these fibers were shorter $(<8 \mu \mathrm{m})$ and thinner $(<0.25 \mu \mathrm{m})$ fibers. Such short, thin asbestos fibers should not be excluded from those contributing to the induction of human malignant mesothelioma, since they are the major asbestos fibers detected in the lung and the mesothelial tissues in the mesothelioma cases. To assess asbestos fibers associated with the induction of malignant mesothelioma, asbestos fibers in both the lung and the mesothelial tissues should be investigated.

6) The present study supports that chrysotile asbestos can induce human malignant mesothelioma. In some of the mesothelioma cases, asbestos fibers detected in both the lung and mesothelial tissues $(15 / 64 ; 23.3 \%)$, or in lung tissue alone $(10 / 43 ; 23.3 \%)$ or in mesothelial tissues $(30 / 44 ; 68.2 \%)$ were exclusively chrysotile fibers.

\section{References}

1) Suzuki Y, Churg J (1969) Structure and development of the asbestos body. Am J Path 55, 79-107.

2) Wagner JC, Berry G, Skidmore JW, Timbrell V (1974) The effects of the inhalation of asbestos in rats. $\mathrm{Br} \mathrm{J}$ Cancer 29, 252-69.

3) Sébastien P, Janson X, Gaudichet A, Hirsch A, Bignon $\mathrm{J}$ (1980) Asbestos retention in human respiratory tissues: comparative measurements in lung parenchyma and in parietal pleura. In: Biological effects of mineral fibres, ed. by Wagner JC, 30, 237-46, IARC Scientific Publications, WHO/International Agency for Research on Cancer, Lyon.

4) Dodson RF, Williams MG, Corn CJ, Brollo A, Bianchi C (1991) A comparison of asbestos burden in lung parenchyma, lymph nodes and plaques. Ann NY Acad Sci 643, 53-60.

5) Kohyama N, Suzuki Y (1991) Analysis of asbestos fibers in lung parenchyma, pleural plaque and mesothelioma tissues of North American insulation workers. Ann NY Acad Sci 643, 27-52.

6) Suzuki Y, Yuen S, Ashley R, Calderaro A (1998) Asbestos fibers and human malignant mesothelioma. In: Proceeding of the 9th International Conference on Occupational Respiratory Diseases, Kyoto, Japan 1316 October, 1997, eds. by Chiyotani K, Hosoda Y, Aizawa Y, 709-13, Elsevier.

7) Dodson RF, O' Sullivan MF, Huang J, Holiday DB, Hammar SP (2000) Asbestos in extrapulmonary sitesomentum and mesentery. Chest 117, 486-93.

8) Goodwin MC, Jagatic C (1971) Asbestos and mesothelioma. Environ Res 3, 391-416.

9) Auerbach O, Conston AS, Garfinkel L, Parks VR, Kaslow HD, Hammond EC (1980) Presence of asbestos bodies in organs other than the lung. Chest 77, 133-7.

10) Churg A, Wiggs B, Depaoli L, Kampe B, Stevens B (1984) Lung asbestos content in chrysotile workers with mesothelioma. Am Rev Resp Dis 130, 1042-5.

11) McDonald JC, Armstrong B, Case BW, Doell D, McCaughey WTE, McDonald AD, Sébastien P (1989) Mesothelioma and asbestos fiber type-Evidence from lung tissue analyses. Cancer 63, 1544-7.

12) Roggli V, Pratt PC, Brody AR (1993) Asbestos fiber type in malignant mesothelioma: An analytical scanning 
electron microscopic study of 94 cases. Am J Ind Med 23, 605-14.

13) Dufresne A, Bégin R, Churg A, Massé S (1996) Mineral fiber content of lungs in patients with mesothelioma seeking compensation in Québec. Am J Respir Crit Med 153, 711-8.

14) Dodson RF, O’Sullivan M, Corn CJ, McLarty JW, Hammar, SP (1997) Analysis of asbestos fiber burden in lung tissue from mesothelioma patients. Ultrast Path 21, 321-36.

15) Stanton MF, Layard M, Tegeris A, Miller E, May, M, Morgen E, Smith A (1981) Relation of particles dimension to carcinogenicity in amphibole asbestoses and fibrous minerals. JNCI 67, 965-75.

16) Case BW, Sébastien $P$ (1987) Environmental and occupational exposure to chrysotile asbestos: a comparative microanalytic study. Arch Environ Hlth 42, 185-91.

17) Sébastien P, McDonald JC, McDonald AD, Case BW, Harley R (1989) Respiratory cancer in chrysotile textile and mining industries: exposure inferences from lung analysis. Br J Ind Med 46, 180-7.

18) Case BW, Sébastien $P$ (1989) Fibre levels in lung and correlation with air samples. In: Non-occupational exposure to mineral fibers, eds. by Bignon J, Peto J, Saracci R, 90, 207-18, IARC Scientific Publication, International Agency for Research on Cancer, Lyon.

19) Case BW (1991) Health effects of tremolite. Now and in future. Ann NY Acad Sci 643, 491-504.

20) Morinaga K, Kohyama N, Yokoyama N, Yasui Y, Hara I, Sasaki M, Suzuki Y, Sera Y (1989) Asbestos fibre content of lungs with mesotheliomas in Osaka, Japan: A preliminary report. In: Non-occupational exposure to mineral fibres, eds. by Bignon J, Peto J, Saracci R, 90, 438-43, IARC Scientific Publication, International Agency for Research on Cancer, Lyon.

21) Hiroshima K, Suzuki Y (1993) Characterization of asbestos bodies and uncoated fibers in lungs of hamster. $\mathrm{J}$ Electron Microsc 42, 41-7.

22) Kohyama N, Kyono H, Yokoyama K, Sera Y (1993) Evaluation of low-level asbestos exposure by transbronchial lung biopsy with analytical electron microscopy. J Electron Microsc 42, 3150-327.

23) LeBouffant L, Martin JC, Durif S, Daniel H (1973) Structure and composition of pleural plaques. In: Biological effects of asbestos, eds. by Bogovski P, Gilson JC, Timbrell V, Wagner JC, 8, 249-57, IARC Scientific Publication, International Agency for Research on Cancer, Lyon.
24) Boutin C, Dumortier P, Rey F, Viallat JR, DeVuyst P (1996) Black spots concentrate oncogenic asbestos fibers in the parietal pleura-thoracoscopic and mineralogic study. Am J Respir Crit Care Med 153, 444-9.

25) Smith AH, Wright CC (1996) Chrysotile asbestos is the main cause of pleural mesothelioma. Am J Ind Med 30, 252-66.

26) Stayner LT, Dankov, DA, Lemen RA (1996) Occupational exposure to chrysotile asbestos and cancer risk: A review of the amphibole hypothesis. Am J Public Health 86, 179-86.

27) Asbestos, asbestosis, and cancer: the Helsinki criteria for diagnosis and attribution (Consensus report) (1997) Scand J Work Environ Health 23, 311-6.

28) Landrigan PJ, Nicholson WJ, Suzuki Y, Ladou J (1999) The hazards of chrysotile asbestos: A critical review. Ind Health 37, 271-80.

29) Appel JD, Fasy DS, Kohtz JD, Johnson EM (1988) Asbestos fibers mediate transformation of monkey cells by exogenous plasmid DNA. Proc Natl Acad Sci USA 85, 7670-4.

30) Hei TK, Piao CQ, He ZY, Vannais D, Waldren CA(1992) Chrysotile fiber is a strong mutagen in mammalian cells. Cancer Res 52, 6305-9.

31) Gan L, Savransky EF, Fasy TM, Johnson EM (1993) Transfection of human mesothelial cells mediated by different asbestos fiber types. Environ Res 62, 28-42.

32) Lezon-Geyda K, Jaime CM, Godbold JH, Savransky EF, Hope A, Kheiri SA, Dzmura ZM, Uehara H, Johnson EM, Fasy TM (1996) Chrysotile asbestos fibers mediate homologous recombination in Rat $2 \lambda$ fibroblast: implication for carcinogenesis. Mutat Research 361, 113-20.

33) Okayasu R, Takahashi $S$, Yamada $S$, Hei TK, Ullrich RL (1999) Asbestos and DNA double strand break. Cancer Res 59, 298-300.

34) Stanton MF, Wrench C (1972) Mechanisms of mesothelioma induction with asbestos and fibrous glass. J Nat Cancer Inst 48, 797-821.

35) Wagner JC, Berry G, Timbrell V (1973) Mesothelioma in rats after inoculation with asbestos and other materials. Br J Cancer 28, 173-85.

36) Pott F, Friedrichs KH (1973) Tumoren der Ratte nach i.p.-Injektion faserformiger Staube. Naturwissenschaften 59, 318-24.

37) Suzuki Y, Kohyama N (1984) Malignant mesothelioma following intraperitoneal administration of asbestos and zeolite. Environ Res 35, 277-92. 
38) Cullen MR, Baloyi RS (1991) Chrysotile asbestos and health in Zimbabwe. I: analysis of miners and millers compensated for asbestos-related diseases since independence (1980). Am J Ind Med 19, 161-169-542.

39) Finkelstein MM (1989) Mortality among employees of an Ontario factory that manufacture construction materials using chrysotile asbestos and coal tar pitch. Am J Ind Med 16, 281-7.

40) Piolatto G, Negri E, LaV ecchia C, Pira E, Decarli A, Peto J (1990) An update of cancer mortality among chrysotile miners in Balangero, Northern Italy 47, 810 4.

41) Shiqu Z, Yongxian W, Fusheng M, Hongshuen M, Wenzhi S, Zhenhuan J (1990) Retrospective mortality study of asbestos workers in Laiyuan. In: Proceedings of the VII International Pneumoconioses Conference Part II; August 23-26, 1988; Pittsburgh PA. National Institute for Occupational Safety and Health 1242-4. DHHS publication 90-109 part II.

42) Bégin R, Gauthier J, Desmeules M, Ostiguy G (1992)
Work-related mesothelioma in Québec, 1967-1990. Am $\mathrm{J}$ Ind Med 22, 531-42.

43) McDonald JC, Liddell FDK, Dufresne A, McDonald AD (1993) The 1891-1920 birth cohort of Quebec chrysotile miners and millers: mortality 1976-1988. Br J Ind Med 50, 1073-81.

44) Dement JM, Brown DP, Okun A (1994) A mortality among chrysotile asbestos textile workers: Cohort mortality and case-control analyses. Ann Occup Hyg 38, 525-32.

45) Goodwin MC, Jagatic G (1968) Asbestos and mesothelioma. JAMA Letters 204, 1009.

46) Langer AM, McCaughey WTE (1982) Mesothelioma in a brake repair worker. The Lancet Vol. II (November 13); (8307) 1101-3.

47) Huncharek M (1987) Chrysotile asbestos exposure and mesothelioma. Br J Ind Med 44, 287-8 (correspondence).

48) Huncharek M, Muscat J, Capotorto JV (1989) Pleural mesothelioma in a brake mechanic. Br J Ind Med 46, 69-71. 